\title{
THREE EPIC MOTIFS FROM HOMERIC, BYZANTINE, AND MACEDONIAN EPIC POETRY
}

\begin{abstract}
Comparative research of Macedonian epic poetry as part of the South Slavic tradition as it relates to the ancient and Byzantine epics indicates to a series of points of reference and parallels. In some cases, parallels with the Byzantine epic are so developed and precise that influence from one side or the other is quite likely. This text examines the presence and manner of treating three motifs in Homeric, Byzantine, and Macedonian epic poetry about King Marko: Aornos or birdless place, conquering or passing a river with a spear, and the ominous singing of a woman. In particular, the possible role of the Macedonian epic poetry as a bridge between the Byzantine epic poems the Song of Armouris and the Digenes Akrites is emphasized in Slavic translations whose manuscripts have been found in Russia during the past two centuries.
\end{abstract}

The evidence is in the details. A. B. Lord

The impetus for this work is the growing interest in comparative research of epic poetry in the Balkans, primarily the South Slavic epic tradition in relation to the ancient and especially Byzantine epic. This interest has not yet taken on a systematic shape and mainly consists of partial research on the style, motifs, and typical themes. ${ }^{1}$

Of particular importance in this area is the study of the Byzantine Song of Armouris and Digenes Akrites, and especially the attempts to explain the genesis of the Slavic translation of the last epic whose manuscripts were found in Russia, beginning from the mid-19-th century onwards under the general title The Deeds of Devgeni (Девгениево деяние). In this context, a discussion in the literature has developed. On the one hand, primarily Russian researchers such as M. N. Speranskij, V. D. Kuzmina, and O. V. Tvorogov advocate the thesis that the translation of the Dignenes Akrites from the original Greek was made in Russia. On the other hand, scholars primarily Western European, such as $\mathrm{H}$.

${ }^{1}$ An attempt to systematically research this agenda was made by the author of this article in the book: V. Mitevski, The Shadow of King Marko. Ancient, Byzantine and Macedonian epic poetry. MANU, Skopje, 2017; pp. 352 (in Macedonian language with extensive Russian and English summaries). 
Grégoire, A. Vaillant, and P. de Odorico argue that the epic was translated from Greek in the southern Slavic areas of the Balkans, and later, due to Turkish conquests, the manuscript was transmitted to Kievan Rus. Because of fierce scholarly debate, southern Slavic traditional epic poetry gained a new meaning and took on a kind of guardian role of the ancient and Byzantine epic. Naturally, arguments are needed to come to a resolution, and those forwarded are not general but rather precise and unequivocal. Such arguments can be discovered, as A. B. Lord says, only in the details, which is to say in the "microscopic analysis" of seemingly insignificant and minor motifs. Their presence and persistent repetition in epic works are the best indication that there are some essential points of reference or influence among different epic traditions.

In one of his texts, Lord made a significant contribution in this regard, pointing to the possible links between the ancient Greek and Roman, the Byzantine, and the Turkish epic traditions on the one hand, and the southern Slavic tradition on the other. He specifically referred to the motif called Aornos, meaning the birdless place. ${ }^{2}$

Some of my perceptions in the Macedonian epic tradition as part of the southern Slavic tradition, especially in the cycle of epic poems about King Marko, point to the presence of the Aornos motif in several songs of which Lord was unaware. In addition, careful analysis of Macedonian songs reveals other such motifs whose traces can be recognized in ancient and Byzantine epic poetry. Two motifs in addition to Aornos are given: throwing a spear across a river and the ominous singing of a woman.

We must note that the Macedonian epic songs which are subject to analysis are taken from authoritative records, most of them from the $19^{\text {th }}$ century, compiled by Macedonian collectors of folk songs and sung in folk Macedonian language ${ }^{3}$.

\section{Aornos or Birdless Place}

Encouraged by the comparative studies of Byzantine epic poetry and the Slavic world by H. Grégoire, Lord explores the motif of the birdless place (Aornos in Greek) and points to its presence in the broader Balkan context, but also beyond it from antiquity onwards. He begins working with this motif in the Deeds of Devgeni (Девгениево деяние), the Slavic version (prose translation) of the Byzantine epic of Digenes Akrites. Interestingly, the Aornos motif is absent from all six of the known Greek versions of the epic, but the motif appears in the Slavic versions that are believed to be translations from a much older Greek

\footnotetext{
${ }^{2}$ Lord, A. B., 1991, Epic Singers and Oral Tradition. Harvard.

(http://chs.harvard.edu/CHS/article/display/6188).

${ }^{3}$ It is primarily the collection of the Miladinovci brothers from Struga and the collection of Marko Cepenkov from Prilep, towns in the modern Republic of Macedonia that were part of the Ottoman Empire in the $19^{\text {th }}$ century.
} 
original. Lord finds it in Tihonravov's version, but the fact is that the birdless place motif can be found in the Pogodin's and Titov's versions too.

In Titov's version, we read how Devgeni violently enters the yard of the home of the Strategist who utters this bewildered and angry statement:

Here in my yard, a bird must not fly, and not even a person can enter. ${ }^{4}$

(Зде в мой двор и птица не смеет залетить, не токмо человек внити.)

In Pogodin's version, Devgeni comes in front of the Strategist's home seated upon a horse, singing and dancing to seduce his daughter, and she sends her handmaiden to warn him of the danger. The handmaiden goes out to Devgeni and finds audacity surprising, adding:

Not even a bird is permitted to pass through the yard. ${ }^{5}$

(Но не смееть птица пролетети мино двора сего.)

When Strategist sees Devgeni in his yard, he is surprised and angry and tells him:

Not even a bird is permitted to pass through my yard, much less a man. ${ }^{6}$

(Зде в мой дворь птица не смеет влететь, ниже человьку вниmu.)

A. B. Lord further reveals the same motif in the Turkish prose romance of Sajjid Battal $\left(14^{\text {th }}\right.$ to $15^{\text {th }}$ century). Here in the fortified mountain passes it said that fortifications are so strong that not even a bird could pass. ${ }^{7}$

Then follow the examples from the Muslim tradition, which Lord refers to as Serbo-Croatian, and from the Macedonian epic tradition. In the first song that was published in the collection from Novi Pazar by Milman Parry in 1934, the hero Gol Alija had become a haiduk and had taken refuge in a cave on Mount Goleš. In Lord's English translation, it reads:

He put the mountain under his order. No bird even dared to fly across it; how then would any human being dare to pass through? ${ }^{8}$

Lord then points to the same motif in the Macedonian poem titled King Marko and Musa Kesedžija" and indicates that he is "very close to

${ }^{4}$ Titov's version, p. 358 line 40.

${ }_{6}^{5}$ Pogodin's version, p. 48 line 47.

${ }^{6}$ Pogodin's version, p. 52 line 16.

${ }^{7}$ Lord, A. B. 1991, chapter 11: "Notes on Digenes Akrites and Serbo Croatic Epic".

${ }^{8}$ Ibidem.

${ }^{9}$ Lord mentions this song with the title Marko Kraljević and Musa Kesedžija, which is typical of the Serbian language, and quotes it as Bulgarian, probably because 
the selection from Sajjid Battal." ${ }^{10}$ Musa Kesedžija has blocked twelve pits and twelve scaffolds on the Vardar River near the city of Demir Kapija:

Birds are not permitted to fly,

how could a man pass. ${ }^{11}$

(та не дава пиле да префркне

камо ли ти човек да премине.)

These two verses occur three times in the same song, imposing a sort of metric formula.

Furthermore, in his comparative study, Lord emphasizes that this motive does not occur only in these three folk traditions (Byzantine, Turkish, and South Slavic), but also much earlier in antiquity.

In Book 12 of Homer's Odyssey, Circe, the witch-goddess, warns Odysseus to be careful when crossing the strait between Scylla and Charybdis by boat because it is dangerous:

Not even a bird can pass through here. ${ }^{12}$

Futhermore, Lord points to the entrance of Avernus in the sixth book of Virgil's Aeneid, described as follows:

There was a wide-mouthed cavern, deep and vast

and rigged, sheltered by a shadowed lake

and darkened groves; such vapor poured from those

black jaws to heaven's vault, no bird could fly

above unharmed. ${ }^{13}$

The poet adds that the place of the Greeks was called Aornos, and describes it as entering the underworld of the dead.

The following example comes from Lucretius who in his De rerum natura provides further information about the Avernian region. It is a "birdless spot" (Avernus locus) close by Cumae where mountains, filled with black sulphur, smoke, all covered with hot springs. ${ }^{14}$

Certainly, according to his teachings, Lucretius does not accept the claim that it is an entry to the underworld, but instead rationally explains that the birds die in flight because of poisoning from sulfur fumes. Based on this overview, Lord concludes that there is some continuity in the traditional presentation of the place that is so awful that

he has used some edition published in Bulgaria. The poem itself is in Macedonian folk language and speaks of Macedonian territories (Demir Kapija and the river Vardar). Here it is quoted under the title according to the edition of the eminent folklorist Kiril Penušliski (v. Penušliski, K. 1983).

${ }^{10}$ Lord, A. B. 1991.

${ }^{11}$ Penušliski, K. 1983, song 73 (Крале Марко и Муса Кесещија).

12 Od. 12.62.

${ }^{13}$ Aeneas, VI. 237-242. Here it is cited according Lord's translation.

${ }^{14}$ De rerum natura, VI. 738-839. 
not even a bird could fly over it, suggesting that perhaps Virgil has given us an indication that the birdless place marks the entrance to the realm of death and of the dead. ${ }^{15}$

At first glance it may seem as such. In addition to this thesis, there are other examples that Lord does not mention. Thus, the "lake without birds" (öopvoऽ $\lambda i \mu v \eta)$ is also found in Sophocles ${ }^{16}$, as well as in a fragment of a satyr-play by Python, who was an author from the 4th or 3rd century B.C. ${ }^{17}$

However, precise analysis does not allow for the tracing of a strict line of continuity, especially not on a meaningful plan. Namely, the mythological representation of the birdless place being meaningfully related to death or the world of the dead can be applied to Homer or Virgil, but such a meaning may not be applied to the Slavic translation of the Byzantine Digenes (Devgeni). It also does not apply in the Turkish or especially in the Macedonian epic sons. That is seen very well from the other four examples in the Macedonian songs about King Marko, which Lord did not mention or did not encounter.

The aforementioned formulaic expression from the song King Marko and Musa Kesedžija is found in the following songs too:

In the song King Marko and Korun Kesedžija, written down in the $19^{\text {th }}$ century, Korun Kesedžija has blocked eighty roads and

does not a bird fly over

and much less a man to pass. ${ }^{18}$

(не остават пиле да прелетат

не пак ушче човек да поминет.)

In the song Seven Heroes and Arapin from the collection of the Miladinovci brothers from the middle of the $19^{\text {th }}$ century, the Black Arab sat in Demir Kapija, just like Musa Kesedžija and

did not a bird pass,

so how could a man pass. ${ }^{19}$

(н' оставаше пиле да помине,

а камо ли човек да помине.)

In the song entitled The Marriage of Marko's Nephew, his nephew from his sister wants to go to capture the snake with three heads so the "Latin King" will offer his daughter's hand in marriage. Marko warns him that this is a dangerous undertaking because the snake

${ }^{15}$ Lord, A. B. 1991.

16 Toševa-Nikolovska, D., 2012, p. 282, note 20.

${ }^{17}$ Ibidem: fr. $1 \mathrm{TGrF}$.

${ }^{18}$ Penušliski, K. 1983, song 77 ( Кралевиќ Марко и Корун Кесещија, source: Ястребов И. С., Обичаи и песни турецких сербов, Санкт Петербург, 1886).

${ }^{19}$ Penušliški, K. 1983, song 82 (Седум јунаци и Арапин, source: Miladinovci’s collection 1861). 
has blocked nine white pathways

and that which flies cannot pass... ${ }^{20}$

(заптисала девет бели друма

а што лета не може да пројде...)

At the end of the song Marko and the Old Maid, which is a parody of the already familiar theme, an old lady closed four paths and

does not allow a little bird to fly. ${ }^{21}$

(не остава врапче шќо да лета).

From the examples given, it is quite clear that in the Macedonian epic tradition, the motif of the birdless place is very present, but not the ancient mythological context which suggests that it is a place connected with death or the world of the dead. Macedonian songs are all about forceful occupation. The same thing can be said of the Muslim song that spatially and linguistically belong to the southern Slavic epic. Interestingly, this is also true of the versions of the Slavic translation of the Byzantine Digenes (Devgeni), because even here it is a well-guarded fortress of the Strategist with a forbidden entrance for the uninvited and is nothing more than a demythologized space.

However, if we keep in mind the relationship between the Macedonian epic poems and the Slavic translation of Digenes, much attention should be paid not only to the fact that the mythological context does not exist on both sides, but the same formulaic expression is used that implies two components:

1. The inability of a bird to fly over the space, and

2. An addition that emphasizes how not even a person may pass.

This dual and developed formula is used in three of the five examples given, namely in the three oldest Macedonian songs whose records date back to the $19^{\text {th }}$ century.

The precise repetition of the formula, both in Macedonian songs and in the Slavic versions of Digenes, points not only to the thought of a close parallel but also to the questions of whether and by whom the motif was so rigidly defined on a formal plan.

Without much hesitation, and in accordance with the aforementioned evidence, the well-argued thesis of H. Grégoire and others on the southern Slavic origin of the Slavic translation of Digenes would give priority to the Macedonian epic tradition. It is an historical fact that after the fall of Byzantium, and then during the Turkish conquests of the Balkan Peninsula, a part of the Christian Slavic population retreated

${ }^{20}$ Penušliski, K. 1983, song 63 (Женидба на Марковото внуче, sung by Koce Stoyanov at 77 years of age from the village of Badar, Skopje, in the "Marko Cepenkov" Archives for folklore in Skopje, 4073).

${ }^{21}$ Penušliski, K. 1983, song 69 (Марко и старата бабетина, sung by Trajce Stojanovski at 83 years of age from the village of Dračevo, Skopje, in the "Marko Cepenkov" Archives for folklore in Skopje, 2318). 
to the north towards Russia. It is also known that many books from Macedonia, mainly translations of religious books from Greek to Slavic language, were transferred to safer places in the north. This process lasted throughout the five-century rule of the Turkish Empire in Macedonia. Hence, it is quite probable that in that migration of people and cultural goods to the north, the Slavic translations of the Byzantine Digenes Akrites took place, which was formerly brought to this region by the Paulicians. $^{22}$

The examples given here are just one segment that points to the centuries-old relationship between the Byzantine and Macedonian epic tradition. There is also an indication of the global thematic plan and the processing of a series of special motifs and typical themes. ${ }^{23}$

In this case, two more concrete examples will suffice that testify to the connection between the Byzantine and Macedonian epic traditions. The next examples are the motifs of conquering a river with a spear, and the ominous singing of a woman.

\section{Conquering (crossing) a river with a spear}

In the poem Marko Kidnaps Angelina, written down by M. Cepenkov, the eminent collector of Macedonian folklore, mostly from the $19^{\text {th }}$ century, King Marko escapes on a horse with the abducted girl while chasing her loved ones. When he reaches the Galička River, he sees that the river's level is deep and is carrying trees and stones, making it practically impenetrable. Then, as in other such occasions, his horse Sarec gives him advice to stick the spear in the middle of a river to stop the trees and stones and then cross the river. Marko considers the advice and then

Marko struck his spear in the middle of the river

and stopped the trees and stones,

the Śarec entered to swim. ${ }^{24}$

(Удрил Марко копје стреде река

и ми запрел дрвја и камење,

та ми влегол Шареи да ми пливат.)

The scene of crossing the flooded river is both dramatic and unrealistic. It is unrealistic not only that Šarec, Marko's horse, talks with his rider, but also because the role of the spear in the whole act is practically incomprehensible. It is inexplicable how sticking a spear in the middle of a raging river can stop the flow of trees and stones that the hero on the horse passes.

\footnotetext{
${ }^{22}$ For the role of the Paulicians in the transmission of theDigenes from the eastern regions of Byzantium to the Balkans, see for example, H. Grégoire, and the authors mentioned above.

${ }^{23}$ For more on this, see V. Mitevski, The Shadow of King Marko.

${ }^{24}$ Cepenkov, M. song 14 (Марко ја граби Ангелина).
} 
This senseless situation can be explained as a product of poetic imagination, but that is still only a partial explanation. The true explanation is namely in the epic convention that stems from the centuriesold poetry tradition of these territories since antiquity. It is known that in epic poetry, rising water, especially river currents, since Homer presents great danger to the hero, and in some cases presents a mortal danger. ${ }^{25}$ For example, in the Book 21 of Iliad, Achilles enters the waters of the Scamander River by killing his opponents. During the duel between Achilles and Asteropay in the waters of the Scamander River, the spear repeatedly plays a significant role until it gets caught in the carriage beside or in the middle of the river. In the end, the god of the river rebels and threatens Achilles that he will swallow him in his waters, and a fight ensues between the hero and the river current.

The parallels between the Macedonian and Homeric epic regarding the motif of the hero fighting with a river remains within the most general framework. Much closer, however, is the parallel of overcoming river in the Byzantine Song of Armouris. The main hero in one place also encounters a flooded river that is difficult to handle for the horseman. That which follows is similar to Marko's action in that the unusual occurrence of a spear also occupies a central place. On his journey in search of his father, Armouris is riding on a horse and encounters the swollen Euphrates river that he can not pass. A Saracen (Arab) notices him from the opposite side and says with irritation that he is making a go of it, because far better Arabic horses can not pass such a flooded river. But Armouris then receives unexpected advice from the Angel who tells him

"Plant your spear in the middle of palm trees..."

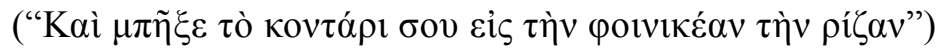

Here again we encounter the strange use of the spear that should be planted in the middle of the palm tree for the hero to cross the river. And here again the question arises: why is it necessary?

An additional explanation in favor of the conventional use of the spear when crossing the overflowing river is found in the Slavic (Pogodin's) version of Digenes (Devgeni). Here, young Devgeni, in a collision with the Byzantine Emperor Basil, crosses the river in an athletic style, leaning on his spear:

And after he said it, he leaned on his spear and jumped over the river.

(И, сказав эти слова, подперся копьем, и перескочил через ре$\kappa y.)^{27}$

${ }^{25}$ Sp. Mills, D. M. 2003.

${ }^{26}$ The Song of Armouris, verses 41-53

${ }^{27}$ Pogodin's version, p. 63 line 32-33. 
The scene is short but effective, and of course conventional. Regarding this fragmentary motif in the Pogodin's version, J. Mavrogordato gives only a brief comment that "it is not anything more than a climax of popular exaggeration". He adds that according to one source, such "pole-jumping" occurs in Russian ballads when crossing the Dnieper River. ${ }^{28}$ It is especially interesting that he himself points out that a similar motif is encountered in the Byzantine novel Kalimach and Khrysorroe ${ }^{29}$ all of which reiterates the thesis that the passage of the river using a spear is a very widespread motif from which the Macedonian author of the song Marko Kidnaps Angelina draws inspiration.

On this occasion, the question arises again: in which direction was this motif spread, from Russia to the Balkans, or vice versa? The presence of the motif in the Mediterranean region in antiquity, as well as the previously noted historical fact about the transfer of Slavic manuscripts due to Turkish conquests from the south of the Balkans to Russia, suggests that the Macedonian epic poetry played the role of a cultural bridge between antiquity and Byzantine tradition on one side and Russia on the other.

\section{The Ominous Singing of a Woman}

In epic poetry, a woman singing is not always a sign of joy and satisfaction. In some epic traditions, this can be an ominous sign that points to danger or brings about an accident to the main hero. One of the famous examples from Homer is the singing of the Sirens at the beginning of the Book 12 in Odyssey. Circe had previously told Odysseus that the song of the Sirens heard while passing strait between Scylla and Charybdis is seductive and dangerous, even fatal to the men that hear their song. That's why he advises him and his shipmates to not get seduced by the singing. Thanks to that advice, Odysseus managed to save himself from the deadly song of the Sirens and not face the fate of his predecessors. It is a general pattern that in other epic traditions takes on specific features.

For example, in both versions of Digenes, that of the Grottaferrata and of Escorial, we encounter a short episode in which the motif of ominous female singing appears. It is seemingly ordinary, but from a comparative aspect, it is an interesting and specific motif. According to the Escorial version ${ }^{30}$, after mastering the dragon and then the lion, Digenes retreats to the tent with his beloved wife, and she asks him to play the tambourine to relax and celebrate the victory over the beasts. Digenes starts to play, and the woman starts singing a love song. However, the music that echoes in the surrounding mountains attracts the three

${ }^{28}$ Mavrogordato, J. (ed.) 1956: XLIII. Here Mavrogordato refers to some of his predecessors like Speranskij and Kalonaros.

${ }^{29}$ Ibid.

${ }^{30}$ Escorial 1139 and forward. 
hundred raiders (apelates) nearby and they approach with the intention of attacking the couple, provoking a struggle with Digenes.

The same motif has been utilized in the Grottaferrata version. ${ }^{31}$ Here again, after mastering the dragon and the lion, Digenes begins to play the cithara at the woman's request, and she again begins her song. Her voice is heard by the three leaders of the forty-five apelates who approach the couple to attack them. Then comes the clash with Digenes.

This episode does not usually attract the attention of researchers, ${ }^{32}$ although in the Grottaferrata version, the singing of Dignenes (in G 4. 260-1) and the singing of his wife (at G 7. 260-1) are compared with the singing of the Sirens of Homer.

However, the comparison with several permutations of the motif in the Macedonian epic poems about King Marko undoubtedly deserve attention. There are at least three songs in which the singing of Marko's wife causes the attention of his enemies.

In the song Marko the Hero and Korun Kesedžia, ${ }^{33}$ Marko takes his young wife to visit her mother. When on the way they run into each other "in the middle of a green mountain," Marko wants the woman to sing him a beautiful song. Her warnings of danger because the band of Korun Kesedžija can hear the song and attack them are in vain. On Marko's insistence she starts singing, and when Korun hears the song, he descends down the road and attacks Marko.

In the song Marko Delibaša and Duka Hajdutin, ${ }^{34}$ we encounter another one of Marko's enemy, but the motif is treated in a similar way. Here Marko leaves with his wife to visit her brothers, and along the way he wants her to sing a song. The woman warns that in the narrow gorges where they pass, Duka Hajdutin is hiding and can hear, but eventually she gives in and sings a song that Duka hears and comes with bad intentions.

In the third song entitled Dimni Marko and the Turkish Duke, ${ }^{35}$ Marko and his wife are going through Pirin Mountain, where he takes a nap and asks the woman to sing him to sleep. And for the third time, Marko does not listen to the warnings and the woman begins to sing, which is heard by Turkish Duke and his three hundred comrades who come to attack.

The triple appearance of this motif in the King Marko cycle sufficiently speaks of its widespread popularity. However, the woman's singing as an incitement to attack the enemy is bizarre if taken as an

${ }^{31}$ Grottaferrata 6. 100 and forward.

32 For example, Dyck (Dyck, A. R., 1987) makes a detailed analysis of the Grottaferrata version (Book VI), but in connection with this episode it is satisfied only with some minor historical details.

${ }^{33}$ Penušliski, K. song 41 (Марко добар јунак и Корун Кесеција).

${ }^{34}$ Penušliski, K. song 40 (Марко Делибаша и Дука Хајдутин).

${ }^{35}$ Miladinovci, song 114 (Димни Марко и Турчин Војвода). 
isolated phenomenon. The power of the epic tradition appears to be the only explanation for the widespread motif that is imposed as a wellknown and conventional episode that testifies to the close creative contacts between Byzantine and Macedonian epic poetry.

\section{BIBLIOGRAPHY}

Beck, H.G., 1971, Geschichte der byzantinischen Volksliteratur. Handbuch der Altertumswissenschaft, Munich.

Beaton, R. - Ricks, D., (eds.), 1993, Digenes Akrites. New Approaches to Byzantine Heroic Poetry. "Variorum", Aldershot (GB) - Vermont (USA).

Cepenkov, M. = Цепенков, М. К., 1972, Македонски народни умотворби. Кн. 1: Народни песни. Скопје.

Dyck, A. R., 1983, "On Digenis Akritas, Grottaferrata Version, Book 5", Greek, Roman, and Byzantine Studies, 24:185-92.

Grégoire, H., 1975, Autour de l'épopée byzantine. "Variorum reprints", London.

Jeffreys, E., (ed.) 1998, Digenis Akritis. The Grottaferrata and Escorial versions. "Cambridge University Press", Cambridge.

Кузьмина, В. Д., 1962, Девгениево деяние (Деяние прежних времен храбрых человек). Москва.

Lord, A. B., 1991, Epic Singers and Oral Tradition, Harvard (http://chs.harvard.edu/ CHS/article/display/6188).

Mavrogordato, J., (eds.) 1956, Digenis Akrites. Edited with an Introduction, translation and Commentary. "Clarendon Press", Oxford.

Miladinovci = Миладиновци, 1962, Зборник 1861-1961. „Кочо Рацин“, Скопје.

Mills, D. H., 2003, The Hero and the Sea. Patterns of Chaos in Ancient Myth. Illinois.

Mitevski, V., 2017, The Shadow of King Marko. Ancient, Byzantine, and Macedonian epic Poetry, MASA, Skopje (Митевски, В., 2017, Сенката на Марко Крале. Античката, византиската и македонската епска поезија МАНУ: Скопје - in Macedonian language with extensive Russian and English summaries).

Odorico, P., 2012, L'Akrite. L'épopée byzantine de Digénis Akritas. “Anacharsis", Toulouse.

Penušliski, К. = Пенушлиски, К., 1983, Марко Крале. Легенда и стварност. Скопје.

Pogodin's version = Кузьмина, В. Д., 1953, „Новый список „Девгениева деяния“, Труды Отдела древнерусской литературы Института русской литераmуры, IX: 339-360. Академия наук СССР, Москва.

Théologistis, H. A., 2012, Chant d'Armouris. Introduction, pp. 211-222, v. Odorico, P. de, 2012

Titov's version = Творогов, О. В., 1981, Девгениево деяние. Подготовка текста, перевод и комментарий О. В. Творогова. - В кн.: ПЛДР. ХІІІ век. с. 28-65, 531-533.

Toševa-Nikolovska, D., 2012, "Satyr-play: Tragedy at play or mockery drama?", Živa antika, Monography no 10: 271-293.

Trapp, E., 1971 (ed.), Digenes Akrites: synoptische Ausgabe der ältesten Versionen. Wiener Byzantinistische Studien, 8, Wien.

Vaillant, A., 1955, "Le Digénis slave", Прилози за књижевност, језик, историју и фолклор, Београд, XXI/3-4> 197-228. 
